\title{
Multimedia Design for Learning Media of Majapahit
}

Silvia Rostianingsih, Michael Chang, Liliana

\author{
Informatics Departments, Petra Christian University \\ Siwalankerto 121-131 Surabaya, Indonesia \\ silvia@petra.ac.id, m26411052@john.petra.ac.id, lilian@petra.ac.id
}

\begin{abstract}
Majapahit was one of the last major empires of the region and is considered to be one of the greatest and most powerful empires in the history of Indonesia and Southeast Asia. However, learning history is became unpopular to young generation. Interactive media can help society to learn history enjoyable. This interactive multimedia will allow the reader to interact with combination of text, image, sound, and animations of Majapahit. There are three aspects of disccusion which are economics, politics, also arts and cultures. Each aspects will provide information related with Majapahit. From the results of questionnaire can be conclude that interactive multimedia form is more interesting than history's books which full of text. The audience is satisfy with the utility and interaction form. Their knowledge also improve after they use the application.
\end{abstract}

Keywords. Majapahit, multimedia, interactive

\section{$1 \quad$ Background}

Majapahit was one of the last major empires of the region and is considered to be one of the greatest and most powerful empires in the history of Indonesia and Southeast Asia. Majapahit was a vast archipelagic empire based on the island of Java from 1293 to around 1500. However, learning history is become unpopular for young generation. Interactive media can help society to learn history enjoyable. Interactive learning media can be use as a learning tool individually (Siagian, 2014). Multimedia technology enhance the knowledge (Kaewkiriya, 2013). Moreover, the interactive media can be accessed through devices that support the technology to open this interactive media. In order to improve the egarness of learning history, this research design a multimedia for learning media of Majapahit. This application is built by Unity 3D which is easily handle complex animation.

\section{Majapahit}

Majapahit was founded by Raden Wijaya. It started when Jayakatwang attacked Singasari and causing Kertanegara killed. At the time when Java Mongol attack Jayakatwang, Raden Wijaya pretend to help the Mongols. After Jayakatwang killed, Raden Wijaya turns against the Mongols and managed to repel the Mongol armies 
from the land of Java. In 1293, Raden Wijaya ascended the throne and the title of Sri Kertajasa Jayawardhana.

There are 4 (four) aspect to be concluded in the design: (1) economics, (2) politics, and (3) arts and culture.

\section{$2.1 \quad$ Economics}

Majapahit was an agrarian and maritime empire. Foreign traders who came to Majapahit came from Campa, Khmer, Thailand, Burma, Sri Lanka, and India. Majapahit is also cooperating with several countries, such as, Campa, Cambodia, Siam, Burma, and Vietnam southern (Aji, 2014). Commodities are brought to the Majapahit are silk and china ceramics, fabrics from India, and incense from Arabic. The goods were exchanged for spices and other agricultural products. Ceramics are came from China and Vietnam (Annam) in the form of plates, bowls, and large glasses. While from Thailand, Majapahit import plates, bowls, and small glasses.

\subsection{Politics}

A king was the highest authority in Majapahit, assisted by Rakryan Mahamantri Kartini occupied by the son of the king and the governing board. They are consisting of Rakryan Mapatih or Patih Mangkubumi, Rakryan Tumenggung, Rakryan Demung, Rakryan Rangga, and Rakryan Kanuruhan. This structure is located in the central government and to areas that are under the king has a similar structure. Majapahit also established relations with other countries to expand trade and to the expansion of the territory of Majapahit.

\subsection{Arts and Cultures}

Majapahit's arts were temples and literaries. There are many temples such Penataran, Sawentar, Tigawangi, Surawana, and Rat. Some temples contained narrative relics and some only had plain temple without relics. The relics are contains history that occurred at that time. For examples, Surawana's relics informs the daily life from Majapahit. The most famous literary works in the Majapahit period which is the book of Negarakartagama which is written by Prapanca (Gunawan, 2013). Art at the Majapahit lies not only in temples and literaries, but there are also dance and puppets. At the time of Majapahit, arts already exists. However, during the reign of the Majapahit arts gradually weakened. Arts are experiencing growth after the collapse of Majapahit post (Aji, 2014).

\section{$3 \quad$ Multimedia}

Multimedia uses different media to convey information as text, audio, graphics, animation, and video, all done interactively (Catwright, 2006). Digital multimedia is a combination of two or more media which is represented in digital form, well 
integrated to be presented, or manipulated by computer programs (Chapman, 2000). Multimedia is divided into 5 format which are:

1. Multimedia as a Tutorial

This format is an interactive multimedia learning tutorials conducted like an instructor or teacher. This format presents the information in the form of text, images, either still or moving, video, sound and graphics.

2. Multimedia as Drill and Practice

This format is used to train skills so the users have a proficiency in a skill or mastery strengthens the theory of a concept. This format is also equipped with the correct answer and an explanation of the answer.

3. Multimedia as Simulation

This format has the learning objectives which are trying to emulate a process that occurs in the real world so that users can experience the real world simulations. Examples aircraft simulation.

4. Multimedia as an experiment and Experiment

This format is almost the same as the simulation only this format is usually found in the laboratory of biology, physics, and chemistry that has practical activities so the user can develop experiments.

5. Multimedia as Games

Games are intended to archieve learning process by playing game.

The interactive multimedia elements are text, picture, sound, animation, video. The text is the basic of the information provided by application. The text itself is composed of several symbols, alphabet, and numbers. Image has always been an important part in human oriented multimedia because of the visual (based on sight). Voice is one of the multimedia elements which is interesting and unique than the other multimedia elements. Sound provide information to users and indulge the senses of hearing from user. Animation is a sequence of static images. Animation usually made specifically to help users to illustrate a concept that is becoming a learning requires animation. A video shows the picture of life, so the information is more accurate and interesting.

In order to create interactive multimedia, we must determine objectives of the project. The purpose of the project maybe seen already very obvious but here meant more specific and clear as possible to assist within the project. Second, we must understand the audience, include age range, sex, particular interest, and also level of education. Notice also what the audience experienced a hearing or visual impairments so on. Through the multimedia, audience will be passive or active and also educate or simply entertain. Third, design information should be neatly arranged in a group and not jumping from one to the other information. Forth, interface design should be clear, structured, and understandable. Last, we must test the result to make sure each finished work on a project. Well-designed materials induced positive emotions and facilitated comprehension (Plass, 2014). 


\section{$4 \quad$ Multimedia Design}

\subsection{Structure of Content}

The media is divided into 4 (four) aspects which are (1) History of Majapahit, (2) Economics, (3) Politics, and (4) Art and Culture. The economics explains trade's lane and rivers as a major role in the trade at the time. It also explains which countries are liaised with Majapahit. The politics explains the kings whom rule the kingdom. The arts and cultures explains the historical relics. The structure would be:

1. Majapahit
(a) History
(b) Genealogy of the kings
(c) Rebellion
(d) Expansion

2. Economic

(a) Agriculture

(i) Type of farming

(ii) Farming technology

(b) Trade

(i) International trades

(ii) Goods

(iii) Currency

(iv) Market

(c) Industry

(i) Type of industry

(ii) Technology

(d) $\operatorname{Tax}$

(i) Description

(ii) Type of tax

(iii) Tax collection mechanism

3. Politic

(a) Society and the political system
(i) System
(ii) Environment

4. Art and culture
(a) Ancient
(i) Temples
(b) Religion
(i) Siwa-Budha
(ii) Islam
(c) Revolution
(d) Ceramic craft
(e) Statue 
(f) Metal

(g) Performing

(h) Literature

\subsection{Multimedia}

Multimedia template is divided into 6 (six) which are image, animation, 3D object, initial menu, menu and blank section. Button is design with a vintage style considering the year of Majapahit. Background is relating to the history of the paper that has a very long and brownish in color so it seems like in historical times. Shapes both alone and in conjunction with warm color induced positive emotions (Plass, 2014).

3D object templates display explanations accompanied by a 3D object and description. User can rotate the $3 \mathrm{D}$ object by the $\mathrm{y}$-axis and the $\mathrm{x}$-axis. Image template is a template that contains explanations with images relating to the material being described in the template. Animation template associated with an explanation of the content of the material. The purpose of the animation is to help users understand the content of the material being described in the template. Blank template is a template used to display both images, animation, video, 3D objects, as well as the content of the material. The font's type for the description or picture's title are Linotypes Palatino with 15pt size. The font's for the chapter's title is Algerian with 18pt size. The font's type for each button is using Forte with 18pt size.

Table 1. Template

\begin{tabular}{l|l}
\hline \multicolumn{1}{c|}{ Title } & \multicolumn{1}{c}{ Template } \\
\hline Trade & Image \\
Goods & 3D Object \\
Market of trade & Text \\
Tax & Image \\
Tax collection mechanism & Animation \\
Tax allocation & Text \\
Religion & Image \\
Politic & Image \\
Art and culture & Image \\
\hline
\end{tabular}

\section{Implementation}

In the main district of Majapahit, user can view the location by click one of the 12 district. It is also give information who is ruled and the relation of the king. There are 12 buttons with animated color. The color divided into three status: normal (light color), on-hover (normal color), pressed (dark color).

International trade animate the trade lanes by display an object which is move from one place to another place. The object will remain elliptical oval if located on the trade route passing through the sea. The object will change into a round shape and when the trade lanes located on land 
In the culture menu, there is a button marked "king". When the button is pressed, it will display the king who ruled and it will enlarge the picture of king. Pictures of the king who ruled the kingdom of Majapahit is a set of buttons that given the background image of the kings who ruled the kingdom of Majapahit. Animation is given on each button which provide animation in position, size, rotation, color, and magnification. When users make a hover, the image will be enlarged in size to 400x400 and the position of the image is also changed to be in the right side of the page. If the user has not click the button hover, the image automatically shrink according to the size of the button.

Hampir disetiap halaman dapat dijumpai kotak kecil berisikan tanda Tanya yang berputar 360 derajat pada sumbu Y. Kotak tanda tanya tersebut berisi informasi tambahan mengenai penjelasan yang dibahas pada halaman tesebut yang terletak di belakang kalimat yang ingin diberi informasi tambahan dengan mengeluarkan kotak yang berisi infomasi tambahan tersebut ketika user melakukan hover pada kotak tanda tanya tersebut. Cara penganimasiannya menggunakan fitur animasi dari button, kotak tanda tanya yang berputar 360 derajat menggunakan component button script animasi berupa animation yang di-auto-generate sehingga bebas memberikan animasi dalam posisi, ukuran, rotasi, warna maupun perbesaran. Dalam keadaan normal kotak tersebut diberikan animasi per 30 detik berputar sebesar 90 derajat sampai pada detik ke-2 menjadi 360. Animasi dari button diulang secara otomatis sampai user berpindah halaman ke halaman selanjutnya. Ketika user melakukan highlighted pada button maka dilakukan animasi pada "caption" yang merupakan child dari parent button dengan mengubah ukuran, posisi dan warna pada "caption" yang berisi informasi tambahan dari penjelasan materi yang ditempatkan pada posisi tertentu di halaman tersebut. Apabila user sudah tidak melakukan hover pada button maka "caption" secara otomatis ukurannya kembali seukuran dengan button dan posisi dari "caption" juga kembali pada posisi dimana letak button berada.

Almost in every page can be found a small box containing question marks that rotates 360 degrees on the Y-axis. The question mark box contains additional information when the user hover on the question mark box. The box that rotates 360 degrees is using the component button animation script that are auto-generated so freely give animation in position, size, rotation, color and magnification. Under normal circumstances the box is given a 30 second animation rotates by 90 degrees until the secondto-2 to 360 .

\section{$6 \quad$ Results}

The sub menu of economics section is the origin of goods. Fig. 1 shows the globe spin to match the position of the selected country (Khmer country). 


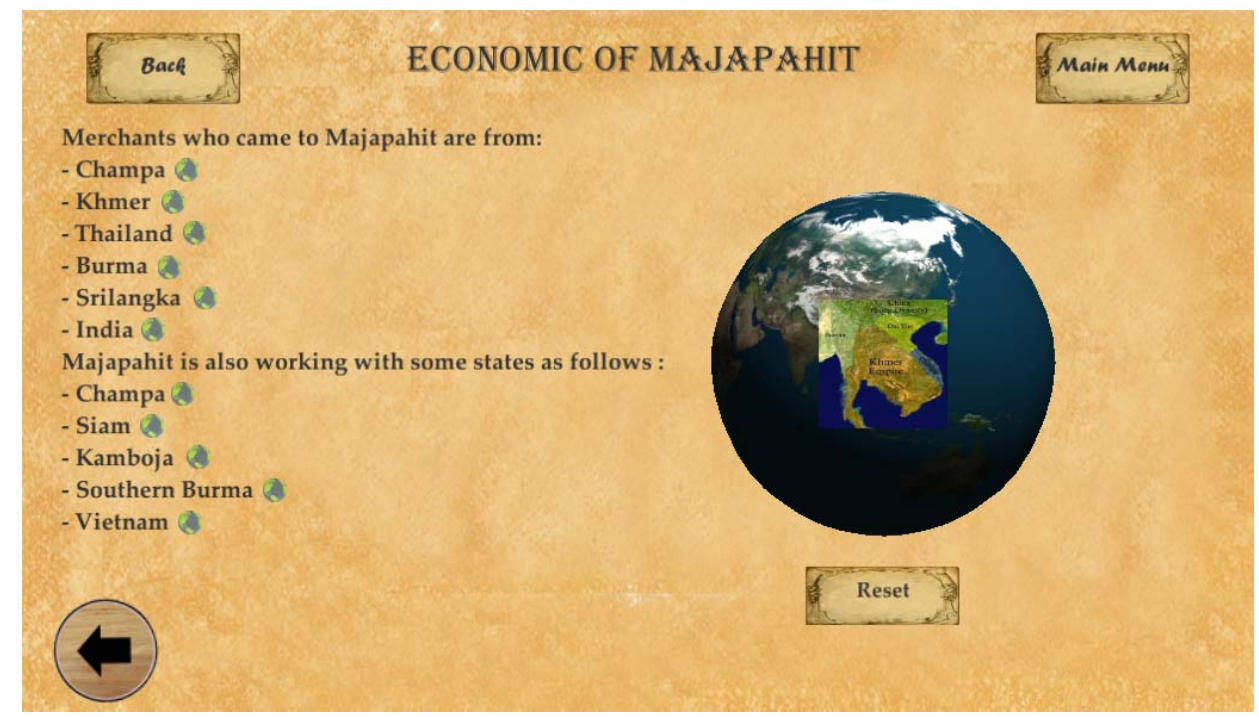

Fig. 1. Origin of Goods

In order to describe the 12 district of Majapahit, user can choose the district's button and the map will show the area with a bright color and brief information about the area (name and image of the king). Fig. 2 shows the information of Matahun's districts which rules by Rajasawardhana. Fig. 3 shows the animation of the trade's lane. The green cirle will move along the lane path to indicate the route.

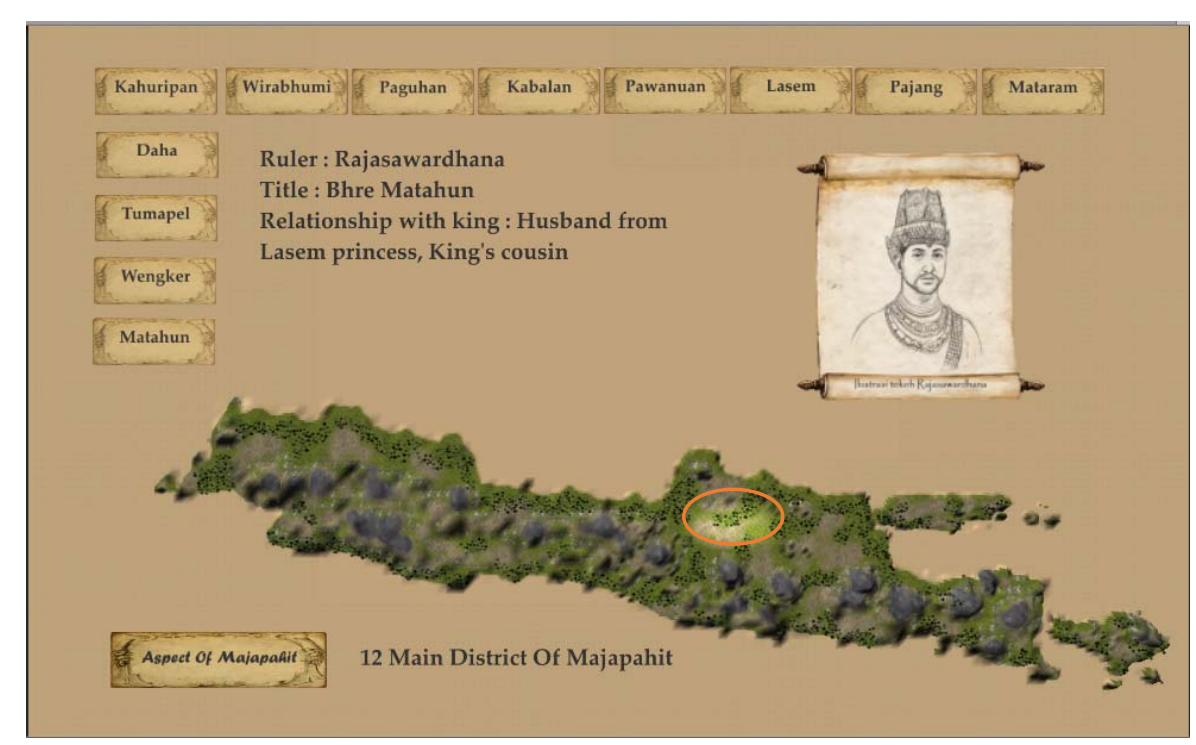

Fig. 2. 12 Main Disctricts 


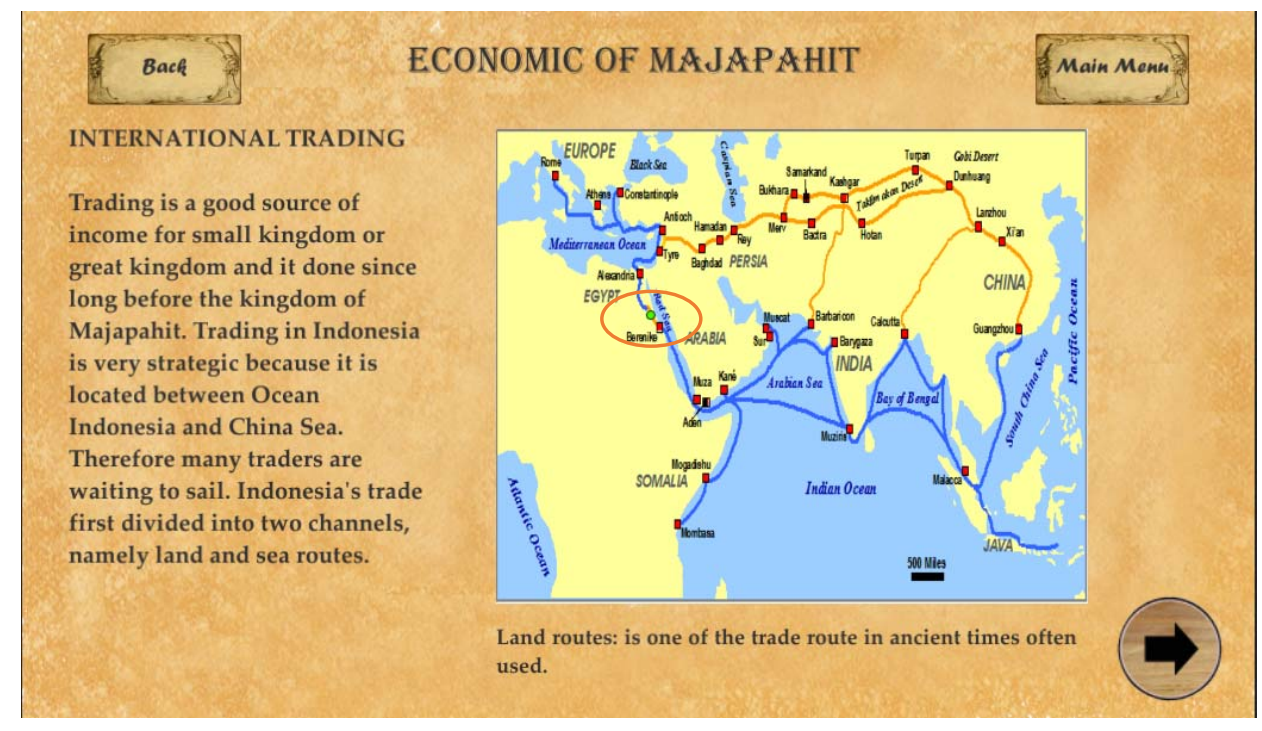

Fig. 3. Lane of Trade

This learning media is tested againts 32 people. The results of questionnaire can be seen in Table 2. The results are 96,9\% found the utility of the application is good, $78,1 \%$ found the interactive of the application is good, $62,5 \%$ fount that their knowledge is improve, and 56,3\% are eager to learn more about Majapahit.

Table 2. Results of Questionnaire

\begin{tabular}{|l|r|r|r|}
\hline \multicolumn{1}{|c|}{ Description } & \multicolumn{1}{c|}{ Good } & \multicolumn{1}{c|}{ Average } & \multicolumn{1}{c|}{ Poor } \\
\hline Utility & $96,9 \%$ & $3,1 \%$ & $0,0 \%$ \\
\hline Interactive & $78,1 \%$ & $15,6 \%$ & $6,3 \%$ \\
\hline Improve your knowledge & $62,5 \%$ & $37,5 \%$ & $0,0 \%$ \\
\hline Willingness to learn more & $56,3 \%$ & $28,1 \%$ & $15,6 \%$ \\
\hline
\end{tabular}

\section{Conclusions}

From the results of questionnaire can be conclude that interactive multimedia form is more interesting than history's books which full of text. The audience is satisfy with the utility and interaction form. Their knowledge also improve after they use the application. 


\section{Acknowledgment}

We would like to thank the KOPERTIS disctrict VII Jawa Timur for the support of this work through project (DIPA Kopertis No. 023.04.2.415015/2014 dated 5 Desember 2013).

\section{$9 \quad$ References}

1. Plass , J. L., et al.: Emotional design in multimedia learning: effects of shape and color on affect and learning. Learning and Instruction, http://dx.doi.org/10.1016/j.learninstruc.2013.02.006 (2013).

2. Aji, K. B. and Achmad, S. W.: Ensiklopedia raja-raja nusantara: menyingkap tuntas riwayat hidup raja-raja nusantara. Indonesia, Araska (2014).

3. Chapman, N. And Chapman, J.: Digital cartography 3rd edition. John Wiley \& Sons, (2009).

4. Gunawan, R., dkk: Sejarah Indonesia kelas X. Jakarta: Politeknik Negeri Media Kreatif, (2013).

5. Siagian, S., Mursid, Wau, Y.: Development of interactive multimedia learning in learning instructional design. Journal of Education and Practice Vol. 5 No. 32, (2014).

6. Kaewkiriya, T.: (2013). A design and development of e-learning content for multimedia technology using multimedia game. International Journal of Software Engineering and Applications (IJSEA) Vol. 4 No. 6, (2013).

7. Cartwright, W., Peterson, M. P.: Multimedia cartography 2nd edition. Springer, (2007). 